\title{
Mathematical Modelling of Crack Fractography after Implant Failure of Titanium 4.5 LCP Used for Flexible Bridging Osteosynthesis in a Miniature Pig
}

\author{
Alois Nečas ${ }^{1}$, Lucie Urbanová1, Tomáš Fürst² ${ }^{2}$ Pavel Ženčák², Pavel Tuček ${ }^{3}$ \\ ${ }^{1}$ Department of Surgery and Orthopaedics, Small Animal Clinic, Faculty of Veterinary Medicine, \\ University of Veterinary and Pharmaceutical Sciences, Brno, Czech Republic \\ ${ }^{2}$ Department of Mathematical Analysis and Applications of Mathematics, ${ }^{3}$ Regional Centre of Advanced \\ Technologies and Materials, Palacky University in Olomouc, Faculty of Science, Olomouc, Czech Republic \\ Received October 26, 2010 \\ Accepted November 24, 2010

\begin{abstract}
Biomechanics of fracture fixation and testing of mechanical properties of bone/implant construct from the viewpoint of checking the strength and resistance ability to acting forces are of current interest. Computer modelling known as mathematical modelling is regarded as an alternative to mechanical testing of properties on a testing machine. As a result, we get a 3D model of a real object (i.e., implant for fracture fixation in our case), which can be exposed to deformation processes in the environment of the mathematical software in order to characterize forces acting on the implant and subsequently analyze the forces causing the implant failure (broken plate). The goal of this study was to employ mathematical-statistical modelling for determination of forces that caused failure (broken implant) of a five-hole titanium $4.5 \mathrm{~mm}$ Locking Compression Plate. This plate has been used for flexible bridging osteosynthesis of segmental femoral diaphyseal defect in a miniature pig to investigate bone healing after transplantation of mesenchymal stem cells in combination with biocompatible scaffolds. Mathematical modelling has been performed with COMSOL Multiphysics software. Numerical study that describes deformation processes taking place in implant failure demonstrates the possibilities of deformation of five-hole titanium $4.5 \mathrm{~mm}$ LCP in the case of exceeding the elastic limits of a material. Knowledge of the forces acting on implants used for fracture fixation acquired from mathematical modelling might be used in clinical practice in order to prevent undesirable implant failure.
\end{abstract}

Plate, bone defect, fracture, deformation, crack driving face, stress field

Segmental bone defects in the form of comminuted fracture constitute a frequent problem in veterinary medicine (Hulse et al. 1997). In clinical practice, various methods of fixation are used (Hulse et al. 1997). Every method has advantages and disadvantages and it is not simple to choose a suitable method of fixation for a given type of fracture to secure the optimal process of bone recovery. In cases of comminuted fractures with loss of continuity of bone column, an anatomic reduction is not possible; an osteosynthesis using the bridging plate is frequently used (Koch 2005; Nečas et al. 2007). Likewise, after bone tumour excision, it is necessary to perform bridging osteosynthesis. Similar situation (segmental ostectomy) has been induced in experimental study dealing with segmental bone healing (Nečas et al. 2010a,b). The function of the bridging plate is to prevent undesirable dislocation of bone fragments as a result of action of shearing and bending forces within the fracture line (Koch 2005). Satisfying this point is crucial from the viewpoint of possible implant failure due to incapability to sufficiently withstand all the acting forces that have been not accurately described in animals yet. In the bridging fracture fixation, the implant failure and bone nonunion can be a problem. Therefore, there are attempts to support healing of the bone by transplantation of mesenchymal stem cells in combination with biomaterial scaffolds (Crha 2009), similarly to the healing of physeal and articular cartilage lesions (Jančář et al. 2007; Koláčná et al. 2007; Krupa et al. 2007; Plánka et al. 2007; Varga et al. 2007; Míčková et al. 2008; Planka et al. 2008; Jančář et al. 2009; Plánka et al. 2009a,b; Nečas et al. 2010c). 
The testing of mechanical properties of some types of fracture fixations and verification and comparison of their strength and resistance ability to various types of acting forces are currently of significant scientific interest as evidenced by some studies (Hulse et al. 1997; Zahn et al. 2008; Filipowicz et al. 2009, Urbanová et al. 2010). However, in these studies, it is not clearly defined which acting force causes eventual implant failure. The above-mentioned studies focus on ex vivo testing of strength of various bone-implant constructs especially upon bending, compression (static of cyclic) and application of twisting forces. All these studies required to produce testing samples and to use a testing machine. In addition, a construction of new experimental device (Tyler et al. 2008) was often needed to simulate a predetermined load of bone/implant construct. As an alternative to mechanical testing, we chose computer modelling (known as mathematical modelling) which allows to create an accurate 3D model of bone/ implant structure that can be exposed to deformation tests in the environment of mathematical software without the need of using test samples.

The issue of deformation of elastic bodies (Brenner and Scott 1994; Ciarlet 2000; Slaughter 2002) can be found in various applications (Ciarlet 2005). There is a set of standard numerical methods and ways how to solve these deformation-oriented problems.

In this study, we report on a mathematical modelling-aided simulation of failure of bone/ plate construct, representing bridging plate osteosynthesis, and determination of the most probable type of possible implant failure. Based on the knowledge of forces acquired from mathematical modelling, we assume that acting on an implant used for a given type of fixation will enable preventing undesirable failure of particular osteosynthesis in vivo. In addition, we propose that this relatively cheap simulation method might replace expensive and time-consuming mechanical ex vivo tests of bone/implant construct performed in a laboratory.

\section{Materials and Methods}

For the mathematical modelling of crack fractography of an implant, a five-hole titanium $4.5 \mathrm{~mm} \mathrm{LCP}$ (Synthes ${ }^{\circledR}$, Switzerland) (Plate X, Fig. 1) was chosen. The implant had been used for a flexible bridging osteosynthesis of segmental diaphyseal defect of left femur in 10-month-old miniature pig, within the scope of broader research project (NPV II 2B06130). The implant was used in an in vivo study of bone healing after transplantation of mesenchymal stem cells in combination with biocompatible scaffolds ( $\mathrm{Nečas} \mathrm{et} \mathrm{al}$ 2009; Nečas et al 2010a; Nečas et al. 2010b). In the experimental animal, we observed implant failure in the form of broken plate; the animal was lege artis euthanized. Femur was excised, the failed implant was removed and passed on for mathematical modelling performed at the Regional Centre of Advanced Technologies and Materials and Department of Mathematical Analysis and Applications of Mathematics at the Palacký University in Olomouc. The mathematical modelling was carried out by means of COMSOL Multiphysics software (a standard package of programs for numerical solution of partial differential equations in 3D).

A simplified geometrical model of this five-hole titanium LCP was created, with the model of two screws attached to it in the most proximal and in the most distal plate holes. The other three holes were left empty (see Fig. 2). Compared to real geometry, this model is simplified substantially, in order to capture only the essential features of the plate. The following parameters were used to simulate the material: Young's modulus $\mathrm{E}=105 \times 10^{9}[\mathrm{~Pa}]$, Poisson's ratio $v=0.33[1]$ and density $\rho=4940\left[\mathrm{~kg} / \mathrm{m}^{3}\right]$.

These parameters then enter the system of second-order partial differential equations in the form

$$
\operatorname{div}[\sigma(x)]+F(x)=0, \text { for } x \in \Omega
$$

where $\sigma$ denotes tensor field of stress $\left[\mathrm{N} / \mathrm{m}^{2}\right]$ and $F$ represents the vector field of density of volume forces $\left[\mathrm{N} / \mathrm{m}^{3}\right]$, which in our case vanishes. The symbol $\Omega$ stands for the three-dimensional set representing the plate.

System (1), is accompanied by the so-called boundary conditions capturing the load by external forces with a known distribution, i.e., for each part of the implant surface (the boundary of $\Omega$ ), stress or strain is specified. The boundary conditions have the form

$$
u(x)=u_{0}(x), \text { for } x \in \Gamma_{1}
$$

and

$$
\sigma(x)=\sigma_{0}(x), \text { for } x \in \Gamma_{2}
$$


where $\Gamma_{1}$ and $\Gamma_{2}$ together form the boundary of the domain $\Omega$. Equation (2) prescribes strain, while equation (3) prescribes stress on the boundary of the body. The freedom in the specification of the boundary conditions allows modeling a broad range of possible loads which can be both feasible and non-feasible in real tensile tests.

The unknown in equation (1) is the stress tensor field, i.e. the result of the solution of the model is the information about the stress (normal and shear stress) at each point of the plate. Deformation of the body (the displacement field) is then related to the stress field by means of the so-called constitution relation which is material-specific. In our case, a version of Hook's Law was used in the form

where

$$
\sigma(x)=C E(x)
$$

$$
E(x)=\frac{1}{2}\left(\nabla u(x)+\nabla u(x)^{\prime}\right)
$$

is the tensor field of small deformations (the symmetrical part of the gradient of displacement $u$ ) and $C$ represents the fourth-order tensor containing the elastic coefficients of the material.

The solution of the mathematical model described by equations (1), (2) and (3) gives deformation of the plate, i.e., displacement of elementary particles of a given body. Deformation field can then be used to calculate the tensor field by means of the Hook's Law. From the components of the stress tensor, the so von Mises stress $\sigma_{\mathrm{M}}$ (von Mises 1913) can be calculated in the following way:

$$
2 \sigma_{M}^{2}=\left(\sigma_{11}-\sigma_{22}\right)^{2}+\left(\sigma_{11}-\sigma_{33}\right)^{2}+\left(\sigma_{22}-\sigma_{33}\right)^{2}+6\left({\sigma_{12}}^{2}+\sigma_{13}{ }^{2}+\sigma_{23}{ }^{2}\right)
$$

The von Mises stress is then used to evaluate the von Mises yield criterion which tells us at which points the elastic limit of the material was reached, or where the material is subdued to the greatest strain.

Two different boundary conditions were used for this simplified model: In the first case, the two screws were loaded with forces of the same magnitude in such a way that the forces pointed one against the other, parallel to the long axis of the plate and parallel to the plate plane. The resulting deformation of the plate was computed and the values of the von Mises stress were colour-coded. In the second case, the two screws were loaded with forces of the same magnitude in such a way that the forces pointed against each other, but this time in a crossway direction at the angle of $45^{\circ}$ to the long axis of the plate, and again parallel to the plate plane. The inner surface of the middle hole was fixed. The resulting deformation was again computed and the values of the von Mises stress colour-coded.

The results describing action of forces and acquired from designed 3D mathematical models of five-hole titanium $4.5 \mathrm{~mm}$ LCP fixed with two screws have been macroscopically compared with an etalon sample in the form of five-hole titanium $4.5 \mathrm{~mm}$ LCP, failed (broken plate) in a real situation (under in vivo conditions), excised from the femur of the miniature pig after failure of fixation of segmental bone defect (Plate XI, Fig. 3).

\section{Results}

In places where von Mises strain exceeded a critical limit, a crack of titanium implant was been observed. On the mathematical model, the values of von Mises stress are depicted by a colour palette where blue colour corresponds to a small strain, whereas red colour corresponds to a large strain.

For 3D model of five-hole titanium 4.5 mm LCP fixed with two screws and forces acting against each other and along long axis of the plate, deformations and colour-coded values of von Mises stress are shown in Fig. 4 (Plate XII). Forces acting in a parallel direction with regard to $3 \mathrm{D}$ plate model long axis gave rise to a symmetrical distribution of strain; we observed bending of the plate model and maximum von Mises stress was reached at outer edges of holes of the implant model.

For the 3D model of five-hole titanium $4.5 \mathrm{~mm}$ LCP fixed with two screws and forces acting against each other but obliquely to its long axis, deformations and colour-coded values of von Mises stress are shown in Fig. 5. Forces acting in the oblique direction with regard to the $3 \mathrm{D}$ plate model long axis gave rise to an asymmetrical distribution of strain. In this case, we observed a tendency of von Mises stress to cumulate around the central hole of the implant model (Fig. 6).

\section{Discussion}

Mathematical modelling of forces acting on a given implant used for fracture fixations may save time and expenses to perform mechanical testing of bone/implant construct on testing machines. 
Creation of the most authentic model of five-hole $4.5 \mathrm{~mm} \mathrm{LCP} \mathrm{(Plate} \mathrm{XII,} \mathrm{Figs} \mathrm{4,} 5$ and 6) having precisely defined shape is a relatively complicated process. Thus, in the first stage, we proposed a simple model (Plate X, Fig. 2) which had been exposed to two ways of possible loading. The values of von Mises stress, when exceeding its critical value leads to the implant failure (broken plate), are depicted on the mathematical model employing a colour palette; blue colour corresponds to small strain whereas red colour corresponds to large strain. This enabled an easy macroscopic comparison of results acquired from loaded 3D mathematical models of a given implant (five-hole titanium $4.5 \mathrm{~mm}$ LCP fixed with two screws) (Fig. 6) with the results observed for an etalon sample (Plate XI, Fig. 3).

The first tested way of loading the implant model (forces acting against each other and pointing in a parallel direction with respect to the plate long axis) gave rise to a symmetrical distribution of strain; we observed a bending of the plate and von Mises strain reached a maximum value at the outer edges of plate holes (Fig. 4). Such acting of a load appears to be easily simulated in laboratory conditions (at load test) and the output can be therefore used for calibration of the model.

In the second tested way of loading the implant model (forces acting against each other and pointing in an oblique direction with respect to the plate long axis), von Mises strains cumulated obliquely around central hole of the implant model. This situation better corresponds to real fractures which, under real clinical conditions, often run in the crossway direction across the middle hole of the plate (Figs 5 and 6). However, even this asymmetrical type of model implant load, used in our numerical experiment, evidently does not satisfy real conditions. On the contrary, the results of our study imply that it is possible to find the setting of boundary conditions so that the critical strain is exceeded in the predefined places. Determination of distribution and magnitudes of forces, acting on the implant and causing its fracture in vivo, will require further exploration of mathematical modelling combinations of various ways of loading the implant. Mathematical modelling enables to perform this task and in comparison with mechanical testing of samples (of bone/implant constructions), it appears to be a method which is relatively cheap, available and less time-consuming.

Analysing the simplified model, we have demonstrated the existence of shearing forces acting asymmetrically in the middle of five-hole titanium $4.5 \mathrm{~mm}$ LCP which cause deformation of the plate in an analogical manner as in the case of a real object, i.e., a broken LCP removed after failure of this implant used for flexible bridging osteosynthesis of segmental femoral diaphyseal defect in a miniature pig during the experimental in vivo study of bone healing after transplantation of mesenchymal stem cells in combination with biocompatible scaffolds (Crha et al. 2009; Nečas et al. 2010a,b).

In our opinion, the method of mathematical modelling might find a wide use in the area of testing of forces acting on an implant used for various types of fracture fixations. Since this method is relatively cheap and less time-consuming, it might contribute to the development of knowledge on biomechanics of fractures and consequently to possible reduction of occurrence or prevention of these undesirable osteosynthesis complications in clinical practice.

\section{Matematické modelování lomu titanové 4,5 mm LCP po selhání implantátu použitého k flexibilní pilířové osteosyntéze u miniaturního prasete}

Biomechanika fixace fraktur, testování mechanických vlastností konstrukce kost/ implantát z pohledu ověřování pevnosti a odolnosti vůči působícím silám je aktuální problematikou. Alternativou k mechanickému testování vlastností na zkušebním stroji v laboratoři je počítačová modelace známá jako matematické modelování. Výstupem tohoto modelování je matematický trojrozměrný model reálného objektu (implantátu k fixaci fraktury), který lze podrobit deformačním testům v prostředí matematických softwarů, s cílem 
charakterizovat síly působící na implantát a následně analyzovat ty síly, které způsobují selhání (zlomení) tohoto implantátu. Cílem této studie bylo využít matematické modelování ke stanovení sil, které způsobily selhání (zlomení) pětiděrové titanové $4,5 \mathrm{~mm}$ Locking Compression Plate, která byla použita k flexibilní pilírové osteosyntéze segmentálního defektu diafýzy femuru miniaturního prasete v experimentální studii jeho hojení transplantací mezenchymových kmenových buněk v kombinaci s biokompatibilními nosiči. Matematické modelování probíhalo s využitím softwaru COMSOL Multiphysics. Numerická studie, která popisuje deformační procesy při analýze lomu implantátu, demonstruje možnosti, při kterých dochází $\mathrm{k}$ deformaci pětiděrové titanové $4,5 \mathrm{~mm}$ LCP, kdy byly překročeny elastické limity materiálu. Poznatky o silách působících na implantáty používané k fixaci fraktur, získané na základě matematického modelování, bude možno využít v klinické praxi při výběru metody stabilizace dané fraktury se snahou předejít nežádoucímu selhání implantátu.

\section{Acknowledgements}

This work was supported by the by the Ministry of Education, Youth and Sports of the Czech Republic (Research Project NPV II 2B06130), grant agency IGA VFU Brno (Project 45/2010/FVL), and MSM 619 895 9214. The authors gratefully acknowledge also the support by the Operational Program Research and Development for Innovations - European Regional Development Fund (project CZ.1.05/2.1.00/03.0058 of the Ministry of Education, Youth and Sports of the Czech Republic).

\section{References}

Brenner SC and Scott LR 1994: The mathematical theory of finite element Methods. Springer, pp. 185-214

Ciarlet PG 2005: An introduction to differential geometry, with applications to elasticity. Springer-Verlag, Heidelberg, pp. 345-385

Ciarlet PG 2000: Mathematical elasticity, Vol. III: Theory of Shells, Series "Studies in Mathematics and its Applications", North-Holland, Amsterdam, pp. 211-270

Crha M, Nečas A, Srnec R, Janovec J, Stehlík L, Raušer P, Urbanová L, Plánka L, Jančář J, Amler J 2009: Mesenchymal stem cells in bone tissue regeneration and application to bone healing. Acta Vet Brno 78: 635-645

Filipowicz D, Lanz O, McLaughlin R, Elder S, Werre S 2009: A biomechanical comparison of 3.5 locking compression plate fixation to 3.5 limited contact dynamic compression plate fixation in a canine cadaveric distal humeral metaphyseal gap model. Vet Comp Orthop Traumatol 22: 270-277

Hulse D, Hyman W, Nori M, Slater M 1997: Reduction in plate strain by addition of an intramedullary pin. Vet Surg 26: 451-459

Jančář J, Slovíková A, Amler E, Krupa P, Kecová H, Plánka L, Gál P, Nečas A 2007: Mechanical response of porous scaffolds for cartilage engineering. Physiol Res 56: 17-25

Jančář J, Vojtová L, Nečas A, Srnec R, Urbanová L, Crha M 2009: Stability of collagen scaffold implants for animals with iatrogenic articular cartilage defects. Acta Vet Brno 78: 643-648

Koch D 2005: Screws and plates. In: AO principles of fracture management in the dog and cat. AO Publishing, Switzerland, pp. 26-50

Koláčná L, Bakešová J, Varga F, Košt’áková E, Plánka L, Nečas A, Lukáš D, Amler E, Pelouch V 2007: Biochemical and biophysical aspects of collagen nanostructure in the extracellular matrix. Physiol Res 56: 51-60

Krupa P, Kršek P, Javorník M, Dostál O, Srnec R, Usvald D, Proks P, Kecová H, Amler E, Jančář J, Gál P, Plánka L, Nečas A 2007: Use of 3D geometry modelling of osteochondrosis-like iatrogenic lesions as a template for press-and-fit scaffold seeded with mesenchymal stem cells. Physiol Res 56: 107-114

Míčková A, Tománková K, Kolářová H, Bajgar R, Kolář P, Šunka P, Plencner M, Jakubová R, Beneš J, Koláčná L, Plánka L, Nečas A, Amler E 2008: Ultrasonic shock-wave as a control mechanism for liposome drug delivery system for possible use in scaffold implanted to animals with iatrogenic articular cartilage defects. Acta Vet Brno 77: 285-296

Nečas A, Proks P, Urbanová L, Srnec R, Stehlík L, Crha M, Raušer P, Plánka L, Amler E, Vojtová L, Jančář J 2010a: Radiographic assessment of implant failures of titanium 3.5 LCP vs. 4.5 LCP used for flexible bridging osteosynthesis of large segmental femoral diaphyseal defects in a miniature pig model. Acta Vet Brno 79: 599-606

Nečas A, Plánka L, Srnec R, Raušer P, Urbanová L, Lorenzová J, Crha M, Jančář J, Gál P 2008: Biomaterials and stem cells in the treatment of articular cartilage, meniscal, physeal, bone, ligamentous and tendineous defects. Acta Vet Brno 77: 277-284

Nečas A, Proks P, Urbanová L, Srnec R, Stehlík L, Crha M, Raušer P, Plánka L, Amler E, Vojtová L, Jančář J 2010b: Healing of large segmental bone defect after implantation of autogenous cancellous bone graft in comparison with hydroxyapatite and $0.5 \%$ collagen scaffold in combination with mesenchymal stem cells. Acta Vet Brno 79: 607-612 
Nečas A, Plánka L, Srnec R, Crha M, Hlučilová J, Klíma J, Starý D, Křen L, Amler E, Vojtová L, Jančář J, Gál P 2010c: Quality of newly formed cartilaginous tissue in defects of articular surface after transplantation of mesenchymal stem cells in a composite scaffold based on collagen I with chitosan micro- and nanofibres. Physiol Res 59: 605-614

Nečas A, Urbanová L, Srnec R 2007: Principy použití LCP plotének. In: Nečas A, Beale BS, Hulse DA, Srnec R a kol.: Osteotomie a nové trendy v léčbě nemocí kostí a kloubů. VFU Brno, pp. 19-22

Plánka L, Gál P, Kecová H, Klíma J, Hlučilová J, Filová E, Amler E, Krupa P, Křen L, Srnec R, Urbanová L, Lorenzová J, Nečas A 2008: Allogeneic and autogenous transplantations of MSCs in treatment of the physeal bone bridge in rabbits. BMC Biotechnology 8: 70, doi:10.1186/1472-6750-8-70

Plánka L, Nečas A, Gál P, Kecová H, Filová E, Křen L, Krupa P 2007: Prevention of bone bridge formation using transplantation of the autogenous mesenchymal stem cells to physeal defects: An Experimental Study in Rabbits. Acta Vet Brno 76: 253-263

Plánka L, Nečas A, Srnec R, Raušer P, Starý D, Jančář J, Amler E, Filová E, Hlučilová J, Křen L, Gál P 2009b: Use of allogenic stem cells for the prevention of bone bridge formation in miniature pigs. Physiol Res 58: $885-893$

Plánka L, Starý D, Hlučilová J, Klíma J, Jančář J, Křen L, Lorenzová J, Urbanová L, Crha M, Srnec R, Dvořák M, Gál P, Nečas A 2009b: Comparison of preventive and therapeutic transplantations of allogeneic mesenchymal stem cells in healing of the distal femoral growth plate cartilage defects in miniature pigs. Acta Vet Brno 78: $293-302$

Slaughter W S 2002: The linearized theory of elasticity, Birkhauser, Boston, Cambridge, p. 543

Tyler JM, Larinde W, Elder SH 2008: A device for performing whole bone torsional testing in a single-axis linear motion testing machine. Vet Comp Orthop Traumatol 21: 478-480

Urbanová L, Srnec R, Proks P, Stehlík L, Florian Z, Návrat T, Nečas A 2010: Comparison of the resistance to bending forces of the 4.5 LCP plate-rod construct and of 4.5 LCP alone applied to segmental femoral defects in miniature pigs. Acta Vet Brno 79: 613-620

Varga F, Držík M, Handl M, Chlpík J, Kos P, Filová E, Rampichová M, Nečas A, Trč T, Amler E 2007: Biomechanical characterization of cartilages by a novel approach of blunt impact testing. Physiol Res 56: $61-68$

Von Mises R 1913: Mechanik der Festen Korper im plastech deformablen Zustand. Göttin. Nachr Math Phys, pp. 582-592

Zahn K, Frei R, Wunderle D, Linke B, Schwieger K, Guerguiev B, Pohler O, Matis U 2008: Mechanical properties of 18 different $\mathrm{AO}$ bone plates and the clamp-rod internal fixation system tested on a gap model construct. Vet Comp Orthop Traumatol 21: 185-194 
Plate X

Nečas A. et al.: Mathematical... pp. 621-626
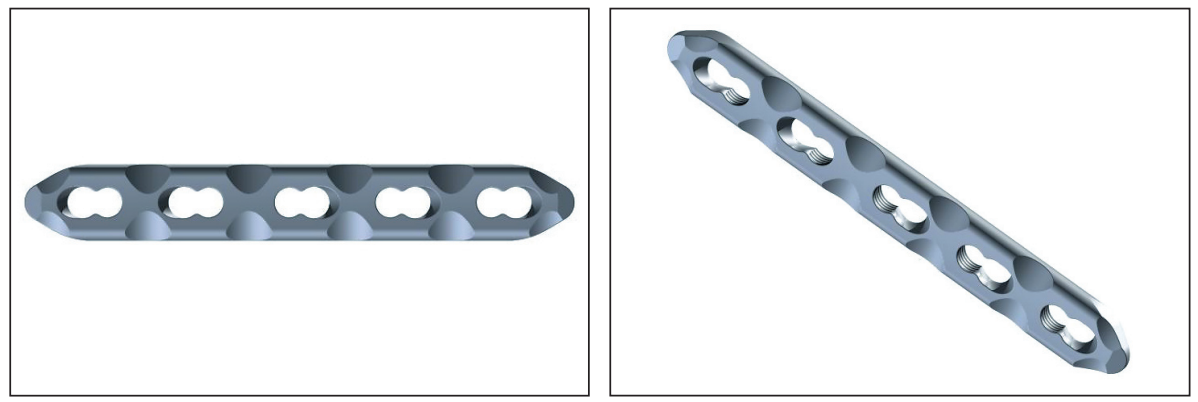

Fig 1. Model of five-hole titanium 4.5 mm LCP $\left(\right.$ Synthes $\left.^{\circledR}\right)$.

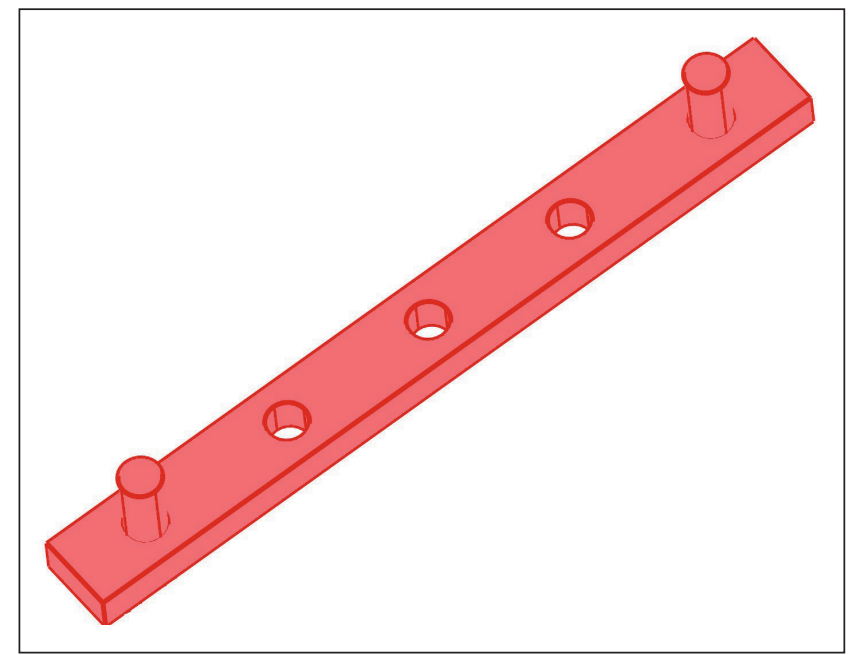

Fig. 2. Geometrical model of titanium $4.5 \mathrm{~mm} \mathrm{LCP}$ fixed with two screws in the most proximal and the most distal plate holes. 


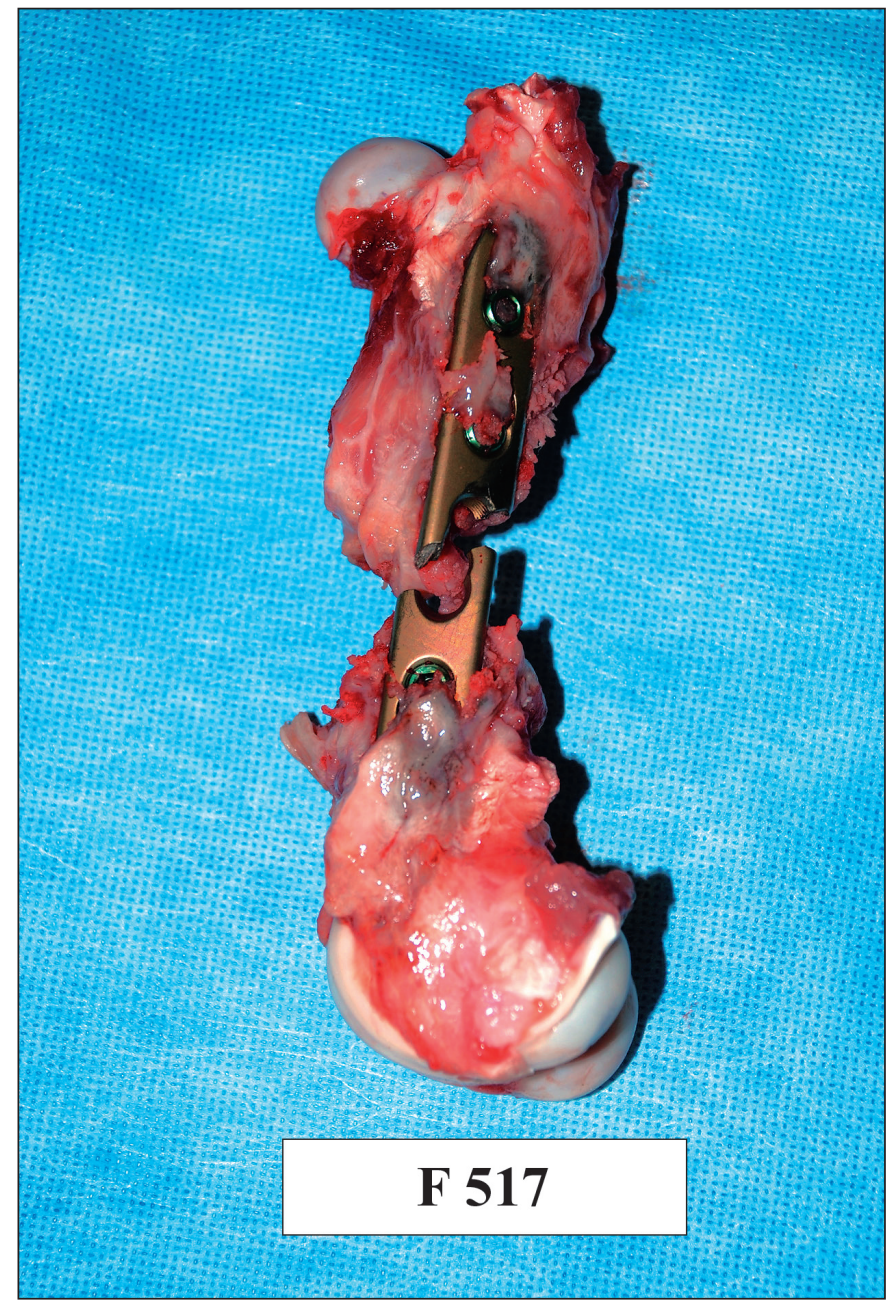

Fig. 3. Etalon sample in the real situation after implant failure (fractured five-hole titanium $4.5 \mathrm{~mm}$ LCP used for flexible bridging osteosynthesis of segmental femoral defect in a miniature pig). 
Plate XII

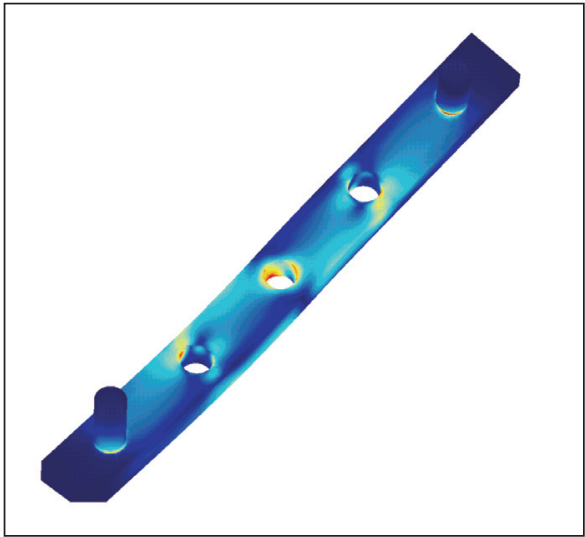

Fig. 4. 3D model of five-hole titanium $4.5 \mathrm{~mm} \mathrm{LCP}$ fixed with two screws - forces acting against each other and parallel the plate long axis. The values of von Mises strain are colour-coded.

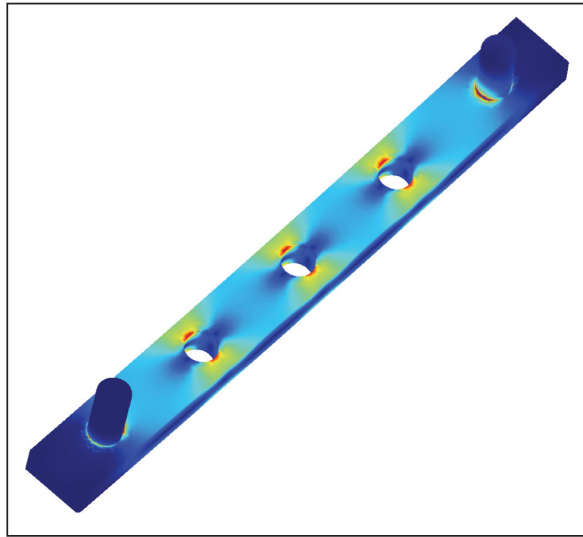

Fig. 5. 3D model of five-hole titanium $4.5 \mathrm{~mm} \mathrm{LCP}$ fixed with two screws - forces acting against each other and oblique to the plate long axis. The values of von Mises strain are colour-coded.

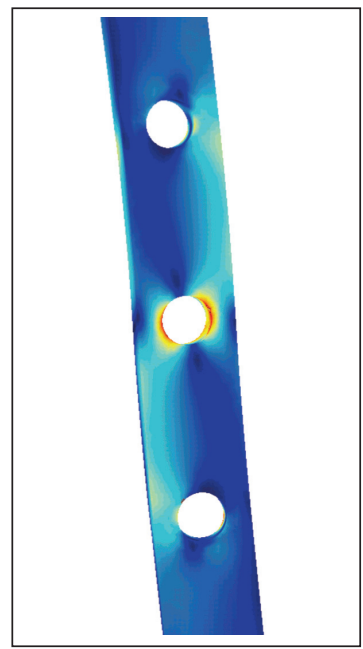

Fig. 6. Result of loading the 3D model of five-hole titanium $4.5 \mathrm{~mm}$ LCP fixed with two screws - forces acting against each other and oblique to the plate long axis. Von Mises strain cumulates in an oblique manner around central plate hole of model implant. 